(C) 1991 ISIJ

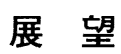

鉄鋼 分析の展望

\section{Recent and Future Trends of Analytical Techniques in Iron and Steel Industry in Japan}

Masao SAEKI

\section{1. はじめに}

鉄鋼業の進歩に真献する関連技術の一つとして分析技 術があり，その最近の進歩発展について今回本誌分析特 集型として集約することは，時宜にかなった付意義なも のと考えられる.それは日本の鉄鋼業が成熟期からさら に変革期にある今日，次の時代を予測し，切り推いてい く师を考える上でも役立つことが多いと思うからであ る.

そこでまず，1950 年以降鉄鋼分析技術の产期的流れ について四つの側酸ら考えてみたい。すなわち（1） 鉄鉱業の技術課題，（2）分析分野での技術課題，（3） その技術们上に奇与する㓮辺技術の発展，（4）新しい 分析技術の研究開発と実用化，である。

鉄鋼業の技術課題については細木繁郎氏の特別講演 ${ }^{11}$ に要約されるように，導入技術の消化，生産性の问上， 環境・省エネルギー，高級化・多様化，弾力的生浐体制， 新規分野への進出であり，これらに対志して（時期的に はそれらの初期段階で) 分析部門での技術課題が設定さ れてきた。一ナで成过技術の発展で特筆すべきは，エレ クトロニクスの進歩とコンピューターの曾及, 分光技 術, 高具空技術, 電子ビームやプラズマ技術の発展があ り，これら環境諸条件と分析技術者（1960 年代までに 世:界のトップレベルになっていた）の研究開発と垁用化 の努力は数多くの成果を生み，鉄䤱業の発展に真献して きた。例えば，転炉操業での発光分析技術，連続鋳造の 普及では鋳片中心偏析の，また鋼材高級化・多様化では 表泊拉よび微細構造の分析・解析技術, 環境問題での極 微量分析技術等があげられる。

さらに 1970 年代以降では機器分析の高性能・システ ム化の時代となり，分析技術でも日本が州界をリードす るようになってきた。この例として発光分析におけるパ ルス分布測定法や製鋼分析窒の無人化等がある.80 年 代からは鉄鋼各社も新素材・エレクトロニクスなど新規
分野へ事業搪人に努め, ppb オーダーの敬微星分析や原 子小度での表洏および微紼構造解析では先進他業界に短 期間で近いつきつつあり，これら技術を派用する社外分 析事業でも総令的分析・解析)を吕く部㜀されている現 状である。この 40 年冨の大きな流机を表 1 に亦す。

この展望では 1970 年から 1990 年までの 20 年䦌につ いて分析・解析技術の主な進少と技術考の做動状沅に関 して概説し，さらに将来への展皆を述べることにしたい。

なお，1970 年代以前の鉄鋼分析技術については本誌

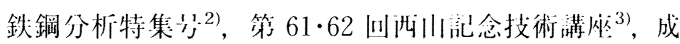
書4)があり，最近の進歩については第 19 回白们记念講

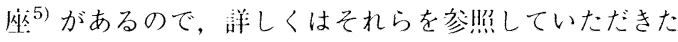
w.

\section{2. 鉄鋼分野での分析·解析技術の進歩}

\section{$2 \cdot 1$ 高感度·高精度分析}

1970 年代の罢境問題では環境分析が仿く関心を集め, 国や地力自治体の規制や企業の社会的思仕からも正しい 測定值を出すことが必須課題となった。䍗境分析ではサ ンプリングの難しさと间時に ppm レベルでの微生域走 量において，従来の吸光光度法では妨娍分も多く適用 困難であったが，原子吸光法( $\mathrm{AAS}$ をを採用し，さらに 抽出分離と組み命わせたり，無炎原了吸光法（FL-AAS）

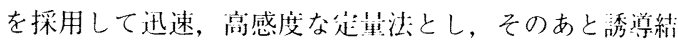
命プラズマ (ICP) 発光分析法の整及により多元素间時 定量も叮能となり大きく進少した。

排ガスや大気中 $\mathrm{NO}_{x}$ 足童では基潐となる化学分析法 が不正確であったため，改艮ナフチルエチレンジアミン

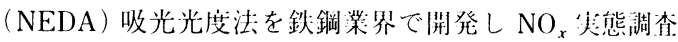
や対策検剧に役立て，さらにISO 法としても提案され， 国内外に頁献している。

鉄鋼中 $\mathrm{C} や \mathrm{~S}$ 定量では製鋼技術の進展に伴い，10 ppm レベルで正確，迅速な足草法が必要とされ，高凨 波加熱㧍よび赤外線吸收測定技術を利用した赤外線吸收 


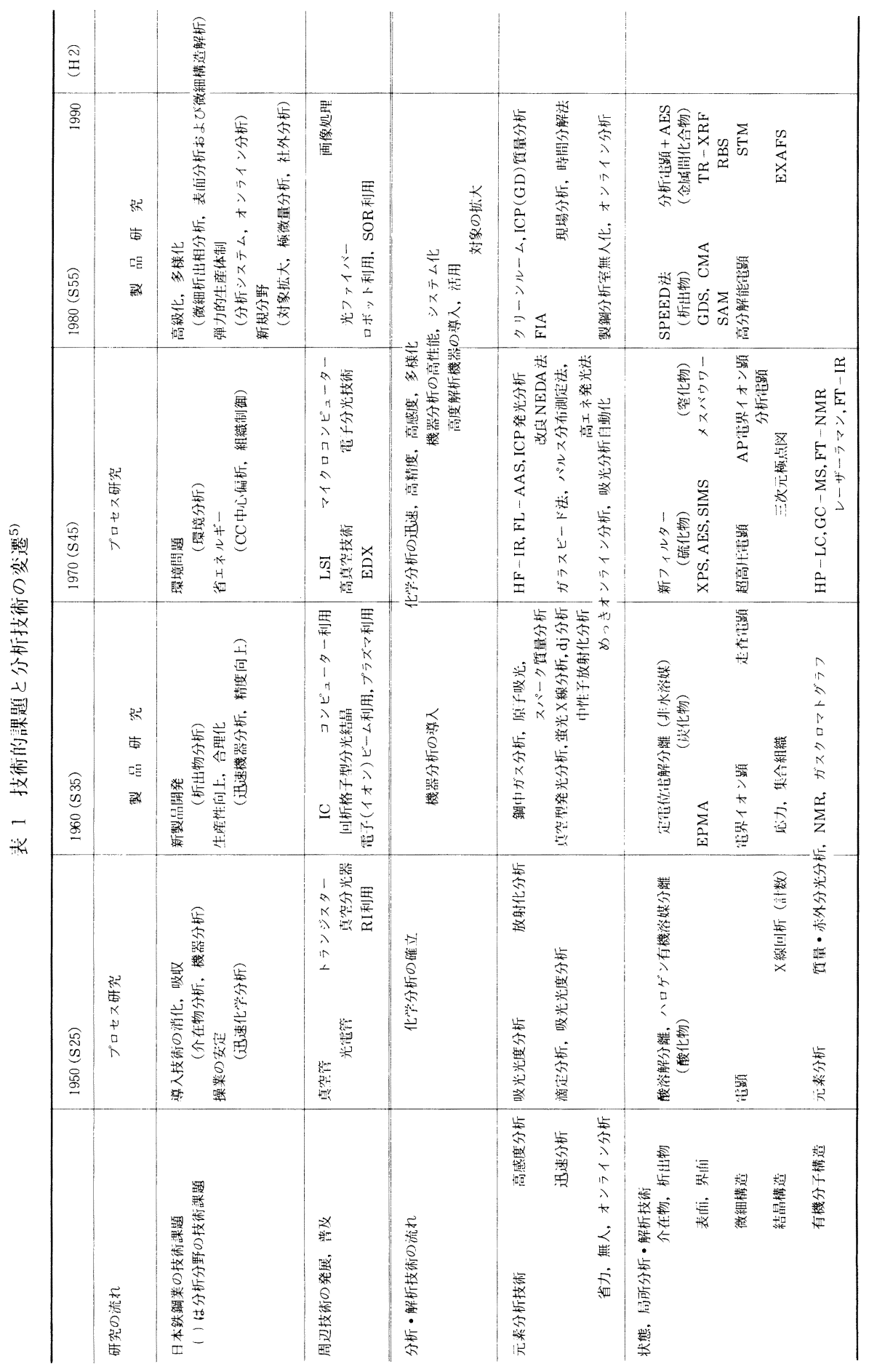


法 (HF-IR) が米国で開発され，いくつかの改良を経て 世界中に普及した。これらは純化学物質を用いて検量線 を作成する操作に改良され ISO 法にもなった。

1980 年代には鉄鋼中金属成分のうち多くの成分定量 法が AAS から ICP 発光分析法に置きかわり，分析能 率を大幅に向上させた。また $10 \mathrm{ppm}$ 以下の極微量分析 が必要となり，日本鉄鋼協会共同研究会鉄鋼分析部会 (以下部会と略す) 化学分析分科会を中心にして分析力 法の共同研究を行い推奨法をまとめた。さらに日本鉄鋼 協会鉄鋼標準試料委員会により高純度鉄標準試料が製造 され、この面でも世界を大きくリードした、いっそうの 高感度化も研究され, フローインジェクション分析法 (FIA)，ICP (またはグロー放電) 質量分析法や放射化 分析法等の新しい物理分析手法も活用され始めた。

\section{$2 \cdot 2$ 迅速分析}

製鋼操業管理のための迅速分析として発光分析法が 1960 年代に定着し，70 年代はコンピューターの利用と 高速発光装置の利用で大きく前進したが，スパーク放電 挙動と放電条件の選択，さらに放電ごとに得られる信篎 処理法を生み出してパルス分布測定法 (PDA 法) が日 本で初めて開発され，鋼中 $\mathrm{Al}$ の形態別定量やほぼ全成 分の精度问上が実現し，少し遅れて高エネルギー発光法 も開発され，これらは国内で広く使われているだけでな く, 外国でも高く評価された。 80 年代は鋼中 $\mathrm{C}, \mathrm{P}, \mathrm{S}$ 定量で微量域へ拡大するために，グロー放電発光分析法 (GDS) や時開分解法等の研究や部会機器分析分科会に おける微量域での分析精度調査や分析条件の改善のため の共闹研究が行われた，一方で製鋼操業現場に䉍易型発 光分析装㯰を設萱し製鋼操業者が自ら分析する試みも迅 速化の手段として行われている.

蛍光 X 線分析法も発光分析法と並んで発展し，70 年 代にはX 線の高強度化や粉体試料のガラスビード作製 による粒度効果の解消技術が先成し，鉄鋼や鉄鉱石， ス ラグを対象とする迅速機器分析としてその地位を盤石な ものとした。 その後, 微量域への定量範用搪大, C 足 量のI夫等がなされ，また極微量分析手法としてユニー クな全仪射蛍光 X 線法 (TR-XRF) が開発された。

鋼中 $\mathrm{O}, \mathrm{N}, \mathrm{H}$ 定量も迅速化が進み, 試料加熱にイン パルス炉を用い大電流で短時間に昇温するす式等を採用 した不活性ガス搬送融解一熱伝導度法が米国で開発され， 70 年代後半には定着した.

\section{$2 \cdot 3$ 省力·無人化，オンライン分析}

鉄鋼業における操業管理用オンライン分析が寒施され たのはめっき鋼板製造ラインが初めてで 60 年代後半の ことである. 70 年代に入ると鉄鋼生产伴びを上まわっ た分析作業量の伸びとなり，分析公に捄ける省力化が緊 急の課題となって, 湿式化受分析を AAS, 溶液発光分 析法に置きかえたり，Mnや $\mathrm{P}$ の吸光光度法を自動化 したりして化学分析公の様相が大きく変わり, さらに
80 年代に入ると価值の低い分析をやめたり,コンピュー ター導入によるシステム化やロボット化で・.部無人化し ながら大幅な要員介理化を達成した(約 $30 \%$ と推定さ れる).

機器分析窒でもコンピューターの覓人により, 発光分 析や蛍光 X 線分析での分析值自動判定や検量線自動較 正が実施され，さらに試料洞製を含む令分析操作を自動 化した無人分析公が 80 年代後半には训现し㮌調に稼動 する等，この面も日本が师界にさきがけた技術の一っで ある。

溶鋼オンライン分析は分析技術者の夢でありこれれ で各国で多くの試みがなされたが笑用には立らなかっ た. 70 年代は固体電解啠を使った䀼淡電池方式による 溶鋼中 O 測定法や，凝湖温度測足による溶鋼中 C 測定 法が研究され実用化された。 80 年代に人ると高級鋼化 や弾力的生産ニーズから肪び開発が月本を中心として始 まり, 数種類のオンライン分析法が研究されている。一 部では転炉火点スペクトル測定による浴鎆中 $\mathrm{Mn}$ 測定 法が実炉で試用され始めた。

\section{$2 \cdot 4$ 介在物. 析出物分析}

1970 年代後半から 80 年代にかけて製鋼技術の進歩, 鋼材の高級化や多様化の中で介在物・析出物分析に対す るニーズが変わってきた，すなわち不純物としての鋼中

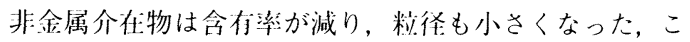
れとは別にマイクロアロイング技術が進み微小複命析出 物やステンレス鋼中金属淌化介物等の解析が必要となっ た。

このための解析内行は，量と組成，絬品構强と整令性， 析出挙動, 粒度と分布, 析出埸听と形態, 等総合的な解 析が必要で材料のキャラクタリゼーションの基盤として その重要性を増している。

湖辺技術としては畐像处理技術や物理的解析機器の進 歩がありこれらに着目し積槧的に取り人れていった時 代である。

80 年代に進少した技術に, 電子線プローブX 線マイ クロアナライザー (EPMA) の高性能化と闫像処理技術 の尊人によって $\mu \mathrm{m}$ オーダーまで高精度に解析叮能とし た新 EPMA（CMA 法）があり，逨鋳鋳师の中心偏析や 介在:物の低減に大いに号献した。

微小析出物のミク口解析に電子踏微鏡や表唒分析法が 総命的に使われるようになり，また，尘枩電䫓による観 察のために鉄䤱試料表面を軽く䉓解して鉄だけを溶解 し，介在物・析出物だけを表泊に残寸選択的巣解エッチ ング (Speed 法) が開発されたり，鋳片のP 偏析を簡 便に検出するりんプリント法も電気化受的乎法の心用と して開発され介在物・析出物分析の適用を公めた。

\section{$2 \cdot 5$ 表面分析}

表面分析技術では 1970 年代から使用され始めたオー 汇工電子分光法 (AES), X 線光電子分光法 (XPS), 
一次イオン啠势分析法 (SIMS) が 80 年代には鉄鍓材料 の解析に们効であることが就され，その地位を磼文し たことが特徽といえる。すなわち, AESにより絬早粰

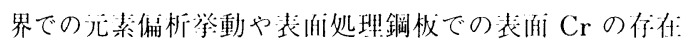
状態が:次儿でミクロに解析でき, XPSによって腐食 初期過程の解析や元絜の化器状態の知兒がえられ，また SIMSにより䤱材衣旧の微望不純物を精度よく，かつ片 所の三次元悄報として得られる筞，他の手法では食く得 られなかった住益な情報が比較的行易に得られるように なった。

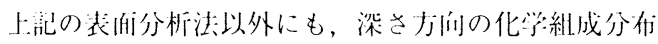
を簡使に分析するグロー放白発光分析法やラザフォード 後方散乱法（RBS），Feや Sn 等特定元素の化学絬令状 態や磁父スピン状態を解析する転換電子メスバウワー分

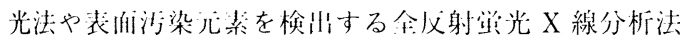
簿がある。

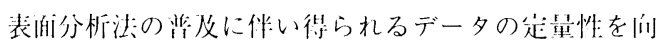
上させるための其间研究が部会表伯分析小委員会で始ま ク，成果をあげた。さらに表淌分析法の標準化のための 国際共间研究湖動がベルサイユサミットの結果として発 足し日本の鉄鋼条社も参加している等，一部の表目分析 法では成熟期を迎えようとしている。

\section{$2 \cdot 6$ 微細構造解析}

1970 年代後半から鉄䤫慗造プロセスの進歩による鋼 材特性の们、は萝しい。例之ば制御1:延や制御冷却筞の

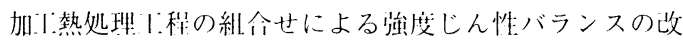

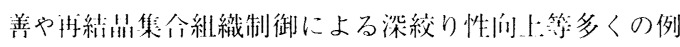
があるが、これらの技術開発を文えたものに電子顕微鏡 (電显と略す)やX 線叫折を駆使したミクロ組織の解析 技術の品度化がある。

微細構造解析に抢いては，金偊組織の観祭や相间定な

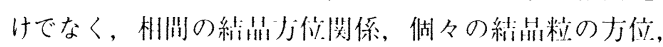
組成分析や内部ひずみなど多㥞な解析が行われ，また相

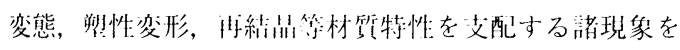
より深く理解するための動的解析も併用される.

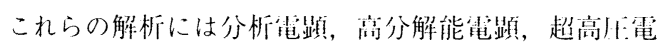

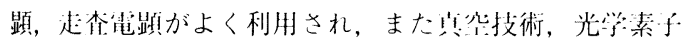
や解析ソフトの進少により品性能化してきた。材料の原 子配列，原子１湖１做の间定とその結果による紬成分析 が行える原チプローブ电界イオン湿微鏡 (AP-FIM) が 活用され始め, さらに80 年代後半に開発された走查卜 ンネル顕微鏡 (STM) やレーザー监微鏡も利用されよう としている.

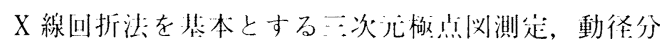
布解析法も利用され，X線の紐來化により $10 \mu \mathrm{m}$ オー ダーまで微紐化されるようになった。 80 年代後半から シンクロトロン放射光 (SOR) の利用が盛んになり, X

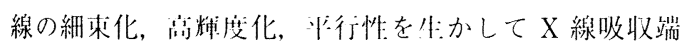
微細構造解析法 (EXAFS) に上り后所的原子構造の解
析や結照構造変化の動的観祭に威力を発搏しつつある.

微細構造解析技術は现在も発展段階にあり, 今後さら に大きな飛躍が期街されている.

\section{$2 \cdot 7$ 有機構造解析}

鉄鋼分野ではこれまで有機構造解析に対してあまり高 度な需要がなく, 石炭, 夕ールや塗料の解析に赤外吸収, 質量分析やガスクロマトグラフ分析が用いられる程度で あった。1970 年代から表面処理皮膜, 压延潤滑油や有 機複令鋼板の解析に, さらに80 年代後半からは新規分 野に研究開発の対象が広がると有機高分子材料やシリコ ンウェファーの解析に, 高度な有機構造解析が必須とな り，各社とも人および設備の増強を网った。例えば，高 速液体クロマトグラフ分析 (HP-LC), ガスクロマトグ ラフ質量分析 ( $\mathrm{GC}-\mathrm{MS})$, レーザーラマン分析, フーリ 工变換赤外吸収分析 (FT-IR) や核磁気基鳴分析 (NMR) が導人され，ようやく化学業界などに近いつい た段階であり，今後いっそうの允実が望まれている。

\section{3. 新規事業分野での分析·解析技術の進歩}

1980 年代には鉄鋼各社も新規事業分野に積極的に進 讪し始め，分析部䅀もこれに十分对忘するようにまず 化学”，新素材に，次いでエレクトロニクスを対象にその 戦力を振りむけていった。六体的には化学，新素材では 炭素䋐維, 有機高分子材料, 炭素材料, ファインセラミッ クス, 水素吸蔵全金, 形状汇憶苓金, アモルファス, 磁 性材料等がまず対象となり，エレクトロニクスではシリ コンウェファーや電子部品に好を注ぐことになった。

鉄鋼分析技術者にとってほとんど朴知の材料であり， まず材料についての知識を勉強し，その上で材料研究開 発にどのような分析・解析技術が必要になるか調べて体 制を遂次構築していったここの10 年间は先進の他業界 に迎いつくべく悬命な努力をした時期で，分析部門に とって 70 年代の環境分析, 60 年代の迅速機器分析拉よ び 50 年代の湿式化兴分析と闹様に時代を代表するキー ワードになるであろう。

新規事業分野の分析・解析技術と鉄鋼分野のそれとは 基本的な而では其通点が多いものの，かなりの点で晎 なっている，例えば前者では商品開発に迎われて基盤的 研究に手がまわらず，また自社に既你事業を持たないの で課題をしぼりにくく流動的である。試料の種類が極端 に多くなり，試料牏製法が多様化し，その上定量すべき 籁网が極微量域から高含有率域まで広く, クリーンルー ムや超高純度試薬を用いたり，さらに機能材料の解析で は最表而単原子層から深さ数 $\mu \mathrm{m}$ までの組成, 構造, 久 陷箵の情報を必要とするように，情報の種類が大幅に増 大したここのため化学的な分析技術の上に物理的な高度 解析技術を総全的に保有していることが必須となってき た。

これらの技術问上のためには分析技術者が日本鉄鋼協 
会や日本金属学会の場で父流するたけけでなく，日本兴術 拨興会, 日本分析化受会, 怂用物理学会筞に参加して技 術を高めたり，国内外の大学:との父流や国家プロジェク トへの参加, 公立研究機関の大形解析設備の借用等, 人 の父流の場が彷米より压倒的に去がったが、これは鉄鋼 分野にもプラスの影響をもたらすことになる。

鈥鋼备社とも事業分野搪大の一環として，これまで蓄 䅡した分析・解析技術を活用して社外からも分析を受部 する扴業を小規模ながら 1980 年代から開始した。これ は多くの民㨽企業が新規事業への進出を目指し，们公门” 研究機関も研究対象を新素材に们ける。この上うな潮流 の中で材料の分析・解析への需要は高まり, 鉄鋼材料を 中心に高いポテンシャルを持つ鉄銅条社への期待があ り，これに㚇えるよう事業化したもので分析技術者の活 踓の場が社外にも開けたともいえる。

社外分析事業の内行は材料の組成分析, 表通分析, 微 絊構造解析, 不機構遗解析また材料の物理試験や物性測 资をべースにした材料評価が主体で，これに齐社の特色 を付加した内埪にして特徽を出しいろいろな形で实行し ている。需要家はエレクトロニクス, 機械, 食属, 化学:

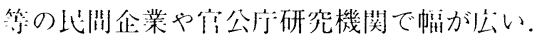

この事業は技術，ソフトが商品であり，常業活動も難 しく, 納期, 価格, 報年内行等で需要家を满足させるこ とはたいへんであるが，膨張を続ける研究支援商業の一 環としての社会的位㯰づけもされ，ますます必要性を高 めている.

\section{4. 分析·解析技術向上のための活動}

分析・解析技術们上の業務は鉄鋼各社の製鉄所，研究 所や大学拉よび研究機関の技術スタッフや研究者によっ て遂行されている。1980 年代は鉄䤱各社とも大幅な令 理化と新規事業分野へのシフトを行ったが，分析部鬥で は製鉄所の技術スタッフが約 $30 \%$ 減少し，研究考数は ほほ横ばいで対象を新規拉業分野に搪げた(1988 年の 淍查では大手 5 社の介計で前者が約 50 名, 後者が約 100 多).

大学篮に拐ける分析研究も対象が新素材, 生体等に変 わり，鉄鋼を対象とする研究窒は 2,3 か所にすぎない。 この傾问は欧米も间じで, 特に米国ではほとんど存在し ないと思われる。

分析・解析技術の全般们倾们として物理的手法による 解析技術が主流となり, 湿式化学分析技術は研究対象と しても少なく, 特に熟練考の確保がむずかしく, 機器分 析のための基準値を求めたり，標準試料の標準值決定の

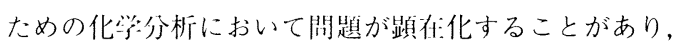
米国を筆䫓に欧洲各国管鉄鋼先進国の其通の恼みとなっ ている。専門分野别では鉄鍓分野の元素・状態分析が減 り, 新規护業分野の表唒分析, 微細構造解析が增大して いる.
鉄鋼分析の其间研究の豩として部会があり，1960 年 (畍利 35 年) 以来浮発な活動をしてきたが，85 年には 従来の 6 分科会加 2 分科会 2 小秋!会の全理化した体 制に改め，より䒠誓的な其润研究を行えるようにした。

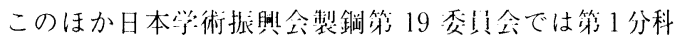
会 (分析) と環境分析協涐会を议組して化受咕測協議会

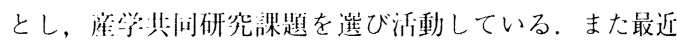
は他の学会の講演会に参玑して新规分野での研究父流を 積杫的に行っている。

外国の鉄鋼分析技術者との父流が频繁になった(例え ばフランスや北欧の分析技術洞涤洲の米汸，日本から $\mathrm{EC}$ 主催の鉄鋼分析[压際会議への参加, ISO/TC17/SC1 および TC102/SC2 の会涐)、こ机はもはや齐国単独で は技術们上が的机なくなり卧際協ノを必須とする時代に 人ったこと，および月本の役制が檕装となったことを意 味している。

\section{5. 標 準 化}

分析技術が他の技術と買なる特徴の‥つに，其通の大 度としての役割から正しい情城であるという密観的認知 が必要でありまま他所でも立施できる滔遍性も必要で, このために手法の標準化が車要となっている。

標準化活動は国内，業界内，社尘よどのレベルで行わ れていたが, 国際的父易の増大に伴って国際標準化機構 （ISO）を中心に国際標準化も推進されている。鉄鋼関 連では鉄鋼分析 ( TC17/SC1), 鉄鈗份分析 (TC102/ $\mathrm{SC} 2$ ), 石䈐コークス分析 ( TC27/SC5), フェロアロイ 分析（TC132，155）ほほる份分析（TC175）があり80 年代以降は日本が国際的にリードする立莂で積敬的に頁 献している.

分析値の保訨や分析す法の検湖のためには呂い標準試 料が必須であるが，月本鉄銅協会が製造する日本鉄铜標 準試料は他国のものとくらべ，信賴性离く，品種の豊窝 さ滗から高い評価を受けている。また慓準武料製造の分

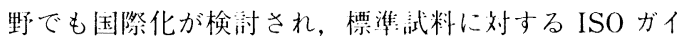
ドラインの制定や各国洲の協力も始まった。

\section{6. これからの分析·解析技術の方向}

\section{$6 \cdot 1$ 高性能化}

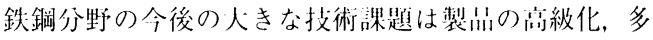

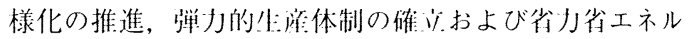
ギー・地球環境対策で, 新规寸業分野では新材料, エレ

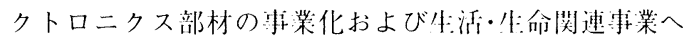
の接近等があり, 分析・解析技術も多血们な攻組が必要 となる.

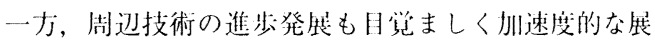
開をみせる，例えば超マイクロコンピューターや $\mathrm{AI}$ 技 術の進歩と普及, 高感度光受素子, 超高突空, 選扑性の よいセンサーの尖用化, マイクロビームの和辉度化や档 


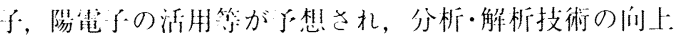
に役立つと想われる。

分析・解析技術の高性能化の技術課題として, 鋼中 C, $\mathrm{S}$ やガス成分の进速機器分析法や杨微量分析法の開発

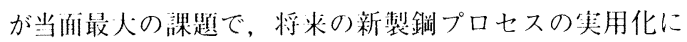
们けて浴銅のオンライン分析法, スクラップ多量使用で のトランプエレメントのモニタリング法の開発も必要で

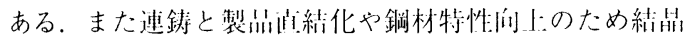
細粒化による組織制御では粒界や微細析讪物の初期生成 段階のミクロ解析技術や䙉令材料の接合界而のミクロ解 析も車装な颗題である。

学働牛:放性の抜本们问上では分析作業の削減と $\mathrm{AI}$ 技 術による無人化の於施が笖がれている。材料構造解析で

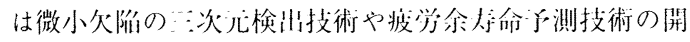

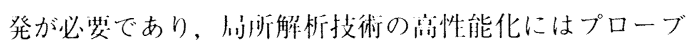

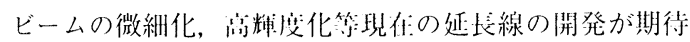

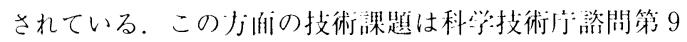

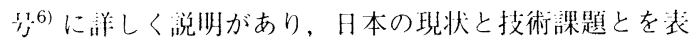
2 に亦す。

\section{$6 \cdot 2$ 材料科学への接近}

研究開発が企業の! 少残りをかける耻贵な戦略となり つつあり, 墑品研究や滴品開発は当然として目的基礎研 究もある比率で行うべきとする意見が強くなっている.

分析・解析技術は齐分野の研究に其通する基礎基盤技 術の一つであり， Materials characterization として重 要な役制を持っている。材料がホすす特性は材料を構成す る構進に起们し，この構造は化峃的組成と物理的構造の
阨酒から考えるべきで， Materials characterizationを しっかり行うことで材料特性と材料構造とを科学的に結 びつけることが川能となり，今後は分析・解析技術者の 側から材料科学:に接近する道があると思う。

最近，材料研究開発において「素機能の解析・評価」 という概念が提唱されている7). 素機能は材料の持つ機 能を発現させる最小単位に打ける機能であり，この最小 単位（通常は数 10 数 100 侗の原子，分子の集合体) において機能とそれをもたらす構造との関係を解析・詊 価によって解明して科学:にまで高めることが重要であ る.ここではメソスコーピック・レベルでの解析が必須 となり，動的，その場分析も重要となる.

\section{$6 \cdot 3$ 分析値の信頼性向上}

分析の機器化, 無人化が進むと人間の千ェックが介在: しないで多量の分析值が壮され，一力で国際交流の增大 から国境を越えた分析所間の分析値の差が問題となる ケースがふえると想され, 分析值の信頼性问上（品質 保酒）が体系的に整備，尖行される時代を迎える。

従来から原子灯材製造に打ける分析值の保証体制等一 部には実施されていたが，今後は全面的にしかも国際レ ベルでの体制確立が望まれる。このためには国内および 国際的にも整令した，分析法の標準化，分析空・人の資 格認坌，技術開発と人の育成，標準試料の整備，これら の実施状沅定期千ェック等全体としての体制を確立。し実 行する必要がある。

表 2 汁測 (解析) 技術の現状と技術的課題 ${ }^{6)}$

\begin{tabular}{|c|c|c|c|c|}
\hline \multirow{2}{*}{ 研究対象分野 } & \multirow{2}{*}{$\begin{array}{l}\text { 我が国の } \\
\text { 技術水準 }\end{array}$} & 技 & 的課 題 & \multirow{2}{*}{ 期待される成果 } \\
\hline & & 全般的課題 & 個 別 的 課 題 & \\
\hline 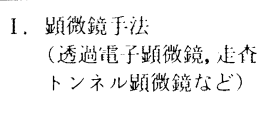 & & 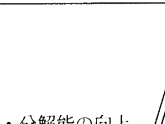 & $\begin{array}{l}\text { ・プローブビーム源の研究開発 } \\
\text { • 探針や位置制御技術, 画像処理技術の } \\
\text { 開発 }\end{array}$ & $\begin{array}{l}\text { - 原子配列観測の高分解能化, たとえ } \\
\text { ば表面・界面や粒界構造の原子レべ } \\
\text { ル理解 } \\
\text { ・高分子や生体物質の広い応用 }\end{array}$ \\
\hline 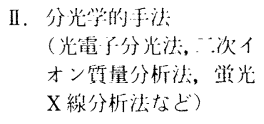 & & - 定量性の向上 / & $\begin{array}{l}\text { ・他の手法との複合化や測定の自動化. } \\
\text { 知能化など } \\
\text { ・ビームのミクロ化・高輝度化 }\end{array}$ & $\begin{array}{l}\text { ・高感度極微量分析 } \\
\text { - 局所分析・解析 } \\
\text { ・物質創製に扔けるその場（in situ） } \\
\text { 計測法 }\end{array}$ \\
\hline 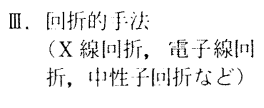 & & •ビームの高輝度， & $\begin{array}{l}\text { ・強力な X 線源の開発 } \\
\text { ・強力な熱・冷中性子源の開発 }\end{array}$ & 状態分析 \\
\hline $\begin{array}{l}\text { IV. その他の手法 } \\
\text { (X線吸收端微組構造 } \\
\text { 分析法, 隄電子消隇法 } \\
\text { など） }\end{array}$ & $\pi$ & 高強度化 & $\begin{array}{l}\text { - 中性原子回折法のための極高真空技術 } \\
\text { 開発 } \\
\text { - 高効摔 X 線光学素子の開発 } \\
\text { • 高強度エネルギー山变陽電子源の開発 }\end{array}$ & \\
\hline 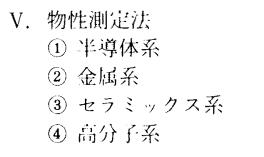 & $T$ & $\begin{array}{l}\text { ・定量性のある迅 } \\
\text { 速な測定法等の } \\
\text { 研究開発 }\end{array}$ & 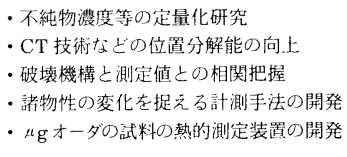 & - 新しい機能の発見 \\
\hline
\end{tabular}




\section{7.おわりに}

分析・解析技術は研究開発や生商における基盤技術と して，日本さらには世界の鉄鋼業の新しい展開に大いに 頁献することが期街されている.

この分野で必要となる技術は, 従来の分析化学と物理 的解析の融合, 総令化, 高性能化した分析・解析技術に とどまらず，材料の本質に迫る材料科学:の一分野として の物性評価技術の両立であり，この意味で「解析科学」 とでも名づける側面がありそうだ。

分析・解析技術者は技術課題解決にあたり，他分野の 技術者や, 外国人とも協力して新技術を創出し, 実用化 していく学際的研究開発を積極的に推進する心構えが以 前にもまして必須となっている。

\section{文献}

1 ）紼木繁郎: 鉄と鎆, 75 (1989), p. 2139

2 ) 池野輝大: 鉄と銅, 60 (1974), p. 1729

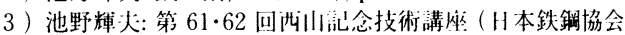
編) (1979), p. 1

4) 日本鉄鎆業に扔ける分析技術（H本鉄銭協会編）（1982）

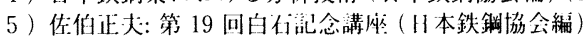
(1990), p. 3

6 )「新材料研究開発に係る計測及び制御技術の高度化のため の重点課題及びその推進方策について」(諮闑第 9 号) に 対する答申 (航空電子等技術番議会編) の概要（昭和 61 年 3 月 28 日), p. 3

7 ) 物質・材料の極微小領域における素機能の汁測・髚価・制御 技術に関する調植 (科学技術订編) (1989) 